\title{
Implementing Process Improvement in Manufacturing Industry: A Case Study
}

\author{
Hatice ESEN and Tugcen HATIPOGLU*
}

\begin{abstract}
In this study, machine production process in a company operating in manufacturing industry is considered and process improvement is provided using simulation. The complicated workflow on the line causes waiting and increases stocks, which in turn leads to bottleneck problems. The main aim of the study is to determine the bottlenecks in the production line and to improve the process by line balancing. Ensuring the regular flow of material in the facility, keeping the usage of human resources at the highest level, using least amount of goods and minimum amount of materials for operations, eliminating bottlenecks and minimizing idle time are provided by assembly line balancing.

The processing time for each machine tool, the arrival time of work pieces belonging to the workshop, and the distributions of these are determined. Simulation models were established for the current situation and the future situation in the study. The output obtained from both models is compared. The reliability of the simulation is verified by applying chi square and $t$ tests between the actual production data and the simulation data. Loss times in the production line were determined and some suggestions were presented for the improvement of lost times such as layout arrangements and workload analysis. Promodel has been chosen as a simulation program. As a result of the study, 5\% improvement for lathe, $56 \%$ for milling machine and $7 \%$ improvement for drill were calculated.
\end{abstract}

Index Terms - Simulation, Process Improvement, Engineering Application, Manufacturing Industry.

\section{INTRODUCTION}

In this study, machine processes in a manufacturing company are examined and process improvement is provided via simulation method. The aim of the study is to identify the bottlenecks in the production line and to improve the process by line balancing.

In the second section of the paper, some studies on process concept, process management and process improvement have been examined.

Finally, the application is presented in the third section. Then the purpose, scope and method of the application have been specified. The current state simulation model is described along with information about the product flow of the machine production line from which the application is made.

With the compilation and preparation of the obtained data, the validation of the model is determined. With this inference, we analyzed the results of the simulation model proposed for the

H. E. is with Industrial Engineering Department of Kocaeli Univesirty, Kocaeli, TURKEY

*T. H. is with Industrial Engineering Department of Kocaeli Univesirty, Kocaeli, TURKEY future situation. The process improvement is achieved by comparing the existing simulation model and the proposed simulation model in the line which has bottlenecks and unbalanced progress.

\section{PROCESS IMPROVEMENT}

Companies has to feed fastly evolving customer requirements to sustain the existence of business. To achieve this result it is necessary to make revisions in the way of doing business and management systems. Therefore importance of process management and process improvement is increasing day by day.

Basic elements of the process are inputs, suppliers, outputs, customers, key performance indicators, customer requirements and process activities. [1]

Process improvement is increasing the process performance. Process performance can be defined as using process sources effectively and tracing the efficiency. After all improvements, by increasing process performance, decreasing reworks and process runs faster and as a result cycle time decreases. Process improvement is eliminating no value added process steps. [2]

In process improvement, products, methods, equipment's, environment, administrative applications, employees and outputs are analyzing by using below elements [3] :

Process Cycle Time

-Customer Satisfaction Rate

-Process Cost

-Customer Response Speed

-Rework Quantity

-Repeated Job Quantities

-Documentation Failures

-Transport Delays

-Total Value Added Steps Time

-Decision Point Quantity

\section{CASE StUdy}

Before the simulation of the production line, the layout of the line in the factory is examined. The layout of the production line is as shown in Figure 1. 


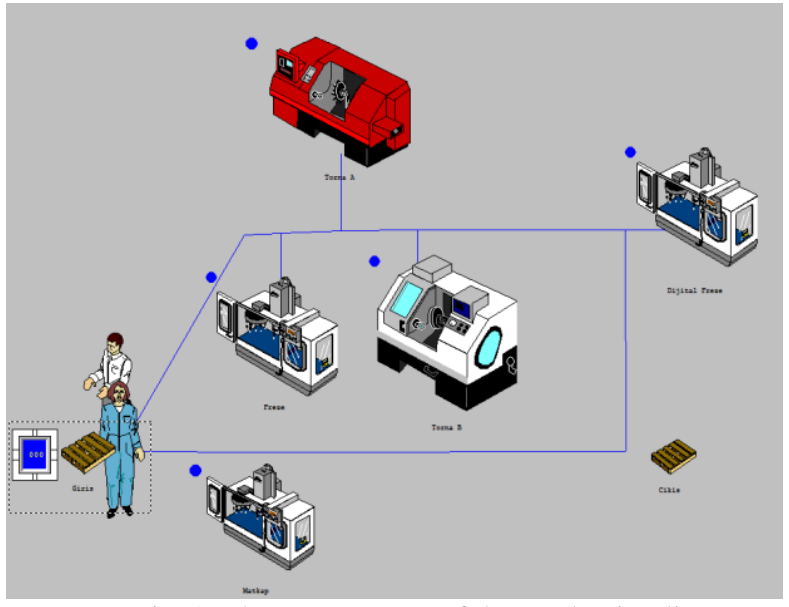

Fig. 1. The current state of the production line.

The distributions for the current situation are given in Table I below. These distributions were found with the Statt: fit program.

TABLE I: DISTRIBUTIONS RELATED TO THE DURATION OF OPERATIONS

\begin{tabular}{llll}
\hline \hline Department & Machine & Distrubition & Explanation \\
\hline Processing & Lathe B & Lognormal & $7 .+\mathrm{L}(0.792,0.709)$ \\
& Lathe A & Uniform & $\mathrm{U}(241,12.2)$ \\
& Digital Milling & Uniform & $\mathrm{U}(91.1,8.1)$ \\
& Milling & Lognormal & $80 .+\mathrm{L}(4.35,5.15)$ \\
Arrivals & Drill & Uniform & $\mathrm{U}(28.5,8.5)$ \\
& Lathe B & Uniform & $\mathrm{U}(76.5,4.5)$ \\
& Lathe A & Lognormal & $221+\mathrm{L}(21.5,18.2)$ \\
& Digital Milling & Lognormal & $102+\mathrm{L}(14.1,4.87)$ \\
& Milling & Lognormal & $103+\mathrm{L}(13 ., 5.34)$ \\
& Drill & Uniform & $\mathrm{U}(1.08 \mathrm{e}+003,540)$ \\
\hline \hline
\end{tabular}

\section{VERIFICATION OF THE MODEL AND ITS VALIDITY TESTING S}

Verification: This stage is applied to verify that the simulation model reflects the actual system in the same way. Entities in the model have been monitored for all flows from "Entry" to "Exit", and it has been observed that entities have passed through all necessary steps in the system in order. Hence, the system verification is provided. So the model represents the real system adequately.

Validity: A stage in which the outputs from the simulation model are compared to the outputs from the real system. At this stage, the outputs obtained from the simulation and the outputs belonging to the real system are compared by making a t-test. If there is no statistically significant difference between the two main masses, it is concluded that the model is valid.

The number of final product is taken as a performance criterion during the model's validity test.

The historical data of the real system for the 11-month period were obtained and compared with the data obtained from the simulation model. The mentioned data are shown in Table II and Table III.
TABLE II: THE DATA OBTAINED FROM THE SIMULATION

Digital

\begin{tabular}{llllll} 
Month & Lathe B & Lathe A & Milling & Milling & Drill \\
\hline January & 1273 & 44 & 58 & 59 & 10 \\
February & 1281 & 44 & 59 & 59 & 11 \\
March & 1274 & 44 & 59 & 59 & 9 \\
April & 1276 & 44 & 59 & 60 & 10 \\
May & 1274 & 44 & 59 & 60 & 11 \\
July & 1276 & 44 & 59 & 60 & 10 \\
August & 1275 & 44 & 59 & 60 & 10 \\
September & 1279 & 44 & 59 & 59 & 9 \\
October & 1273 & 44 & 59 & 60 & 10 \\
November & 1275 & 44 & 59 & 60 & 11 \\
December & 1277 & 44 & 59 & 60 & 9 \\
\hline \hline
\end{tabular}

TABLE III CONTAINS THE ACTUAL DATA TAKEN FROM THE COMPANY. TABLE III: THE REAL DATA

\begin{tabular}{llllll}
\hline \hline Month & Lathe B & Lathe A & $\begin{array}{c}\text { Digital } \\
\text { Milling }\end{array}$ & Milling & Drill \\
\hline January & 1297 & 47 & 64 & 63 & 13 \\
February & 1298 & 48 & 65 & 66 & 11 \\
March & 1294 & 46 & 62 & 61 & 9 \\
April & 1288 & 46 & 62 & 64 & 14 \\
May & 1283 & 45 & 60 & 58 & 12 \\
July & 1261 & 41 & 57 & 59 & 11 \\
August & 1257 & 40 & 53 & 55 & 9 \\
September & 1262 & 41 & 52 & 50 & 9 \\
October & 1271 & 43 & 58 & 60 & 10 \\
November & 1281 & 44 & 58 & 62 & 11 \\
December & 1291 & 46 & 60 & 59 & 10 \\
\hline \hline
\end{tabular}

The t-test is used to confirm the validity of the model. In order for the T-test to be available, the data should show a normal distribution. Chi-square fitness test was performed on each machine to see if the data distributed normally at this point as seen in Figure 2, Figure 3 and Figure 4.

H0: The data normally distributed.

H1: The data do not normally distributed.

Chi-Square Tests

\begin{tabular}{|c|c|c|c|}
\hline & Value & df & $\begin{array}{l}\text { Asymptotic } \\
\text { Significance } \\
\text { (2-sided) }\end{array}$ \\
\hline Pearson Chi-Square & $913^{a}$ & 10 & 1,000 \\
\hline Likelihood Ratio & ,913 & 10 & 1,000 \\
\hline $\begin{array}{l}\text { Linear-by-Linear } \\
\text { Association }\end{array}$ &, 212 & 1 &, 645 \\
\hline $\mathrm{N}$ of Valid Cases & 28116 & & \\
\hline
\end{tabular}

Fig. 2. Chi-square fitness test for lathe-b. 


\begin{tabular}{|c|c|c|c|}
\hline \multicolumn{4}{|c|}{ Chi-Square Tests } \\
\hline & Value & df & $\begin{array}{c}\text { Asymptotic } \\
\text { Significance } \\
\text { (2-sided) }\end{array}$ \\
\hline Pearson Chi-Square & $1,729^{\mathrm{a}}$ & 10 &, 998 \\
\hline Likelihood Ratio & 1,730 & 10 & ,998 \\
\hline $\begin{array}{l}\text { Linear-by-Linear } \\
\text { Association }\end{array}$ & .480 & 1 & ,488 \\
\hline $\mathrm{N}$ of Valid Cases & 1313 & & \\
\hline
\end{tabular}

Fig. 3. Chi-square fitness test for milling. Chi-Square Tests

\begin{tabular}{l|r|r|r} 
& Value & df & $\begin{array}{c}\text { Asymptotic } \\
\text { Significance } \\
\text { (2-sided) }\end{array}$ \\
\hline Pearson Chi-Square &, $902^{\text {a }}$ & 10 & 1,000 \\
\hline $\begin{array}{l}\text { Likelihood Ratio } \\
\text { Linear-by-Linear }\end{array}$ &, 905 & 10 & 1,000 \\
\hline $\begin{array}{l}\text { Association } \\
\text { N of Valid Cases }\end{array}$ &, 153 & 1 &, 695 \\
\hline $\begin{array}{l}\text { a. } 0 \text { cells }(0,0 \%) \text { have expected count less than 5. The } \\
\text { minimum expected count is } 8,65 .\end{array}$ &
\end{tabular}

Fig. 4. Chi-square fitness test for drill.

Chi-square analysis for machine tools was done by SPSS program, H0 is accepted when the data are analyzed.

Since the data are normally distributed, it is now possible to perform a t-test to confirm the validity of the model. With the T-test, it will be investigated whether there is a statistically significant difference between the actual data of the system and the results obtained from the simulation.

$\mathrm{H}_{0}: \mu \mathrm{x}-\mu \mathrm{y}=0$

$\mathrm{H}_{1}: \mu \mathrm{x}-\mu \mathrm{y} \neq 0$

Hypotheses were established for the difference between the two major population averages and t-test was performed for the paired samples at $\alpha=0.05$ significance level. The hypothesis is bidirectional and the degree of freedom is equal " 10 ". The calculated value of $t$ is " $1,007,1,016,1,014,1,008,1,190$ " for lathe_b, lathe_a, digital milling, milling and drilling respectively. Since the calculated $t$ values are smaller than the $t$ value, the $\mathrm{H} 0$ hypothesis is accepted. That is, there is no statistical difference between the mean of the two main masses at 0.05 significance level. The resulting t-test showed that the model was valid.

It has been observed that there are some problems in the current production flow. The main problems identified are listed below:

- Human resources and devices in the production line can not be used effectively. Ineffective used resources lead to inefficient labor, which in turn reduces the number of final products.

- The fact that rarely used drill table is located far from the lathe-b causes the workpieces to be delayed.

- The fact that one worker is working at drill, milling and digital milling machines reduces the number of final products and prevents the efficient use of the machines.

- Overtime of the employee to comply with the term of the contract is not only an additional cost for the enterprise, but it also negatively affects employee performance.

- Time delays and quality problems caused by working fast also negatively affect customer satisfaction and lead to loss of company's confidence.

A future state-of-the-art simulation model and settlement scheme is proposed to overcome the above problems. It is suggested to replace the drill machine with the lathe-b machine. Lathe-b machine, which has frequent work flow, is expected to eliminate time loss. The layout scheme recommended for the operation is shown in Figure 5.

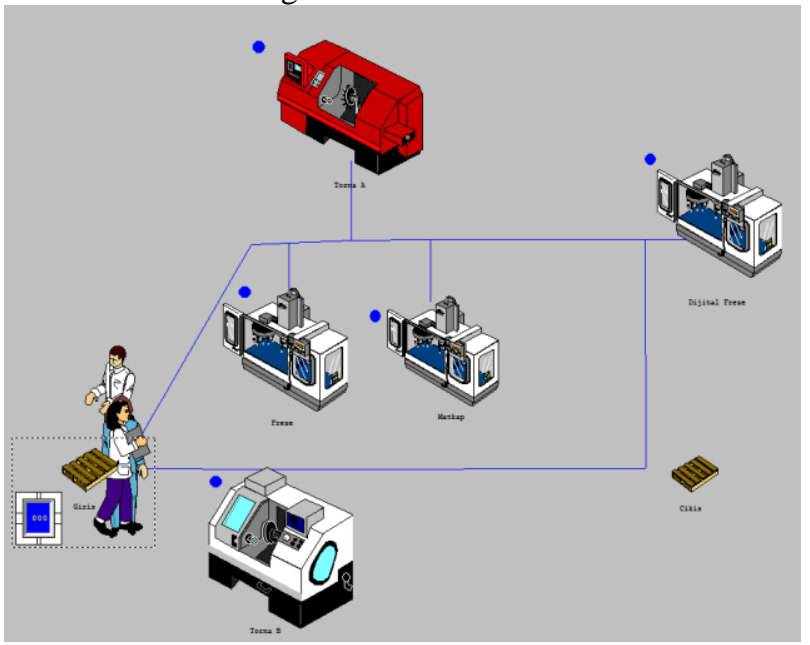

Fig. 5. The future state of the production line.

With the future state simulation model, some arrangements have been made for the present situation. These arrangements are listed below:

- In the current situation simulation, it is seen that the worker working in both milling machine and digital milling machine can not work sufficiently. For this reason a new worker will be recruited for the milling machine. Existing workers will continue to work on the digital milling machine which needs more experience.

- Because of the low work flow on the drill stand, one of the new workers or those who are available in digital milling will be able to deal with the drill stand.

In the future state simulation model, the amount of the final product is increased at the same quality as the changes in the locations of existing machines and the recruitment of a worker.

The comparison of the number of final products taken as a performance criterion compared to the data obtained from the current situation simulation model and the future case simulation model. Based on these findings, 5\% improvement for lathe, $56 \%$ for milling machine and $7 \%$ improvement for drill are provided.

\section{CONCLUSION}

The purpose of this study is to improve process in a company performing in machine manufacturing sector. In this context, the product flow of this company's production line was taken into consideration and the problems of the production were identified as bottlenecks and tried to be eliminated.

In the study, the production line of the company is analyzed. 
First the processing times for each machine and the arrival times of the workpieces belonging to the workshop were determined . Then the distributions were found by the Statt: fit program in the Promodel program. Following the identification of locations, resources, paths and entities, distributions are defined in the Promodel program. After calculating the monthly working time, the simulation was run and the data were analyzed. Then, the reliability of the simulation was verified by applying SPSS program with chi-square and t-test between actual production data and simulation data. Later, loss times in the production line were determined. To improve these lost times, suggestions on the basis of labor power and the machine locations are presented. As a result of these proposals, the system has been simulated with various scenarios with Promodel program. Promodel outputs of the first system and the improved system were compared. As a result of the study, $5 \%$ improvement for lathe, $56 \%$ for milling machine and $7 \%$ improvement for drill were calculated.

\section{REFERENCES}

[1] Bezirci, G. "Hizmet İşletmelerinde Süreç İyileştirme ve Bir Uygulama", İstanbul Technical University, İstanbul, 2006.

[2] Takcı, E. "Bir İmalat İşletmesinde Simülasyon Yardımıyla Süreç İyileştirme Uygulaması: Kayseri Gürkar Tekstil Örneği”, Nevşehir Hace Bektaş Veli Üniversity, Nevşehir, 2013.

[3] Gaga, O. "Süreç Analizi ve Süreç İyileştirme Metodolojisi ve Kısıtlar Teorisi Yöntemiyle Süreç Analizi Uygulaması", Yıldız Teknik Üniversity,esi, İstanbul, 2009.

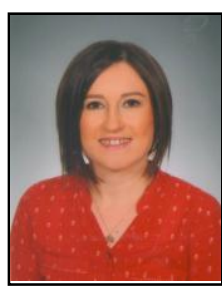

Hatice Esen is currently an Assistant Professor Industrial Engineering Department in Kocaeli University.

She received BS, MSc and $\mathrm{PhD}$ degrees in Industrial Engineering from Kocaeli University.

Her research interests span the fields of production planning, ergonomics and facility layout.

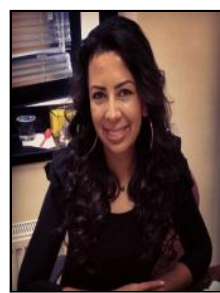

Tuğçen Hatipoğlu is currently a Research Assistant at Industrial Engineering Department in Kocaeli University. She is a phD student in the same institution.

She received her BS degree from Kocaeli University and her MSc degree in Industrial Engineering from Sakarya University.

Her research interests span the fields of artificial intelligence, optimization and statistics. 